\title{
Prevalensi Dan Intensitas Infeksi Trypanosoma Evansi Pada Kuda Di Desa Kabaru, Kecamatan Rindi, Kabupaten Sumba Timur
}

\author{
(PREVALENCE AND INTENSITY OF TRYPANOSOMA EVANSI INFECTION IN HORSE at \\ THE KABARU VILLAGE, SUBDISTRICT RINDI, EAST SUMBA REGENCY)
}

\author{
Mersy Rambu Maramba Ndiha ${ }^{1}$, Ida Ayu Pasti Apsari ${ }^{2}$, I Made Dwinata ${ }^{2}$ \\ ${ }^{1}$ Praktisi Dokter Hewan di Sumba, ${ }^{2}$ Laboratorium Parasitologi Fakultas Kedokteran Hewan, \\ Universitas Udayana, Jalan PB. Sudirman Denasar, Bali \\ Email: rambumn@gmail.com
}

\begin{abstract}
ABSTRAK
Penyakit Surra merupakan penyakit parasit yang disebabkan oleh Trypanosoma evansi. Kejadian trypanosomiasis dipengaruhi oleh berbagai faktor, yaitu kondisi geografis, keberadaan vektor, cara pemeliharaan dan kondisi fisologis hewan. Penelitian ini bertujuan untuk mengetahui prevalensi dan intensitas infeksi T. evansi pada kuda di Desa Kabaru, Kecamatan Rindi. Sampel yang digunakan berupa darah dari 100 ekor kuda yang diambil dari Desa Kabaru. Pengambilan darah dilakukan melalui vena jugularis dan dibuat preparat ulas darah tipis yang diwarnai dengan Giemsa $10 \%$. Preparat ulas darah yang telah diwarnai diperiksa dengan mikroskop untuk mengetahui ada tidaknya infeksi $T$. evansi dan intensitasnya dihitung jumlah rata-rata $T$. evansi per 10 (sepuluh) lapang pandang. Hasil penelitian didapatkan $8 \%$ sampel terinfeksi T. evansidengan intensitas infeksi 13-71 parasitrata-rata sebesar $34.5 \pm 22.7$. Prevalensi infeksi berdasarkan jenis kelamin didapatkan pada kuda jantan sebesar $12 \%$ dan betina sebesar $6.7 \%$. Tidak ada hubungan antara jenis kelamin dengan prevalensi infeksi $T$. evansi.
\end{abstract}

Kata kunci: prevalensi; intensitas; T. evansi; kuda; Desa Kabaru.

\section{ABSTRACT}

Surra is a parasitic disease caused by Trypanosoma evansi. The incidence of trypanosomiasis was influenced by geographical conditions, management system, vector, and host. The aim of this research is to determine the prevalence and intensity of $T$. evansi infection in horse in Kabaru village, subdistrict Rindi. The sample used was blood from 100 horses taken from Kabaru Village. Blood collected was done through a jugular vein and a thin blood smear were made then stained with Giemsa $10 \%$. Preparations of blood smear were examined under microscope to determine the $T$. evansi infection and intensity were calculated on average number of T. evansi in 100 red blood cells. The result showed that $8 \%$ of blood sample infected by $T$. evansi with the infection intensity of 13-71 parasites with an average number of $34.5 \pm 22.7$. The prevalence of sex-based infections was found in males at $12 \%$ and females at $6.7 \%$. There was no significant difference in prevalence of $T$. evansiinfection between male and female horse.

Keywords: prevalence; intensity; T. evansi; horse; Kabaru village.

\section{PENDAHULUAN}

Peternakan merupakan sektor penting dalam menunjang perekonomian di Kabupaten Sumba Timur. Kuda merupakan salah satu ternak yang banyak diternakkan oleh masyarakat Sumba Timur selain sapi, dan kerbau. Berdasarkan data Badan Pusat Statistik Kabupaten Sumba Timur, pada tahun 2015 populasi kuda di Kabupaten Sumba Timur sebanyak 32.355 ekor. Ternak kuda merupakan bagian dari kehidupan masyarakat Kabupaten Sumba
Timur. Disamping memiliki nilai sosial budaya, ternak kuda juga mempunyai nilai ekonomis sebagai salah satu sumber pendapatan masyarakat peternak yang memberikan kontribusi signifikan terhadap Pendapatan Asli Daerah (Pemerintah Daerah Kabupaten Sumba Timur, 2015). PAD Sumba Timur dapat berkurang apabila ada wabah penyakit yang menyerang ternak seperti penyakit Surra yang menyebar luas di beberapa kecamatan di Kabupaten Sumba Timur. 
Surra merupakan penyakit parasit yang disebabkan oleh $T$. evansi dan ditularkan secara mekanis oleh vektor lalat penghisap darah, yaitu lalat dari genus Tabanus, tetapi Stomoxys, Haematopota dan Lyperosia juga dapat menularkan protozoa ini. Parasit ini dapat ditemukan dalam plasma darah dan cairan limfe penderita (Coen, 2011).Surra merupakan penyakit yang serius pada kuda dan unta di Afrika dan Asia, menyebabkan turunnya produktivitas, kematian dan kerugian anatomi (Tehseen, 2016).Surra merupakan salah satu penyakit parasit darah yang penting dan secara sporadik menyebar di beberapa wilayah Indonesia, baik pada area tropis maupun subtropics (Lehane, 2005). Kuda dan unta termasuk hewan yang paling peka terhadap infeksi $T$. evansi yang dapat menyebabkan mortalitas tinggi. Sapi dan babi dapat menderita penyakit ini, tetapi tanda klinis yang muncul kurang parah dibandingkan unta dan kuda (Desquesnes et al., 2013; Eyob dan Matios, 2013). Sedangkan domba, kambing, dan rusa memiliki kerentanan yang rendah terhadap infeksi $T$. evansi (Metanawey-El et al., 2009). Sapi dan kerbau dapat bertindak sebagai reservoir. Kerbau menunjukkan parasitemia lebih lama dan lebih tinggi daripada sapi sehingga kerbau diduga merupakan sumber penularan yang potensial bagi ternak sapi maupun kuda (Mastra, 2011).

Prevalensi $T$. evansi paling tinggi dilaporkan pada kuda berkisar 73\% dibanding kerbau dan sapi di Brazil (Harrera et al., 2004). Total sebanyak 101 sampel darah diambil dari peternakan sapi perah di India menunjukkan prevalensi infeksi $T$. evansi berdasarkan pemeriksaan ulas darah $6.9 \%$ sedangkan dengan deteksi PCR mencapai 46.5\% (Bal, 2014). Laha dan Sasmal (2008) menemukan prevalensi sebesar $12.74 \%$ pada kuda di bagian timur India.Penelitian yang dilakukan di pulau Sumbawa menemukan prevalensi $T$. evansi pada sapi, kerbau, dan kuda masingmasing sebesar $15.45 \%, 26.13 \%$, dan 13,43\% (Mastra, 2011). Manifestasi klinis surra pada hewan bervariasi, infeksi bisa berlangsung akut, subklinis dan kronis. Desquesnes (2004) menyatakan bahwa tanda klinis yang muncul dipengaruhi oleh intensitas infeksi $T$. evansi yang berkembang di sirkulasi darah. Intensitas infeksi $T$. evansi sangat tergantung pada kekebalan tubuh dan kondisi fisiologis dari hospes.

Data terakhir Dinas Peternakan Sumba Timur menyebutkan bahwa penularan penyakit surra di Kabupaten Sumba Timur mulai ditemukan sejak bulan Agustus 2010 yang menyerang ternak kuda dan kerbau, sedangkan pada ternak sapi tidak ditemukan gejala Surra maupun dari hasil pemeriksaan laboratorium. Dinas Peternakan Kabupaten Sumba Timur (2012) melaporkan bahwa kasus Surra di Pulau Sumba Provinsi Nusa Tenggara Timur terjadi pada tahun 2010 - 2011. Kasus tersebut mengakibatkan 4268 ekor ternak (kuda 1608, kerbau 2464, sapi 196) terjangkit penyakitsurra. Kematian akibat surra di pulau Sumba tersebut dilaporkan sebanyak 1760 ekor, terdiri dari kuda 1159 ekor, kerbau 600 ekor dan sapi satu ekor.

\section{MATERI DAN METODE}

\section{Materi}

Objek penelitian yang digunakan dalam penelitian ini adalah kuda di Desa Kabaru, dengan jumlah sampel sebanyak 100 ekor. Bahan-bahan yang digunakan dalam penelitian ini yaitu sampel darah kuda, alkohol 75\%, kapas, kertas tisu, methanol, geimsa $10 \%$ dan minyak emersi. Alat-alat yang digunakan dalam penelitian ini yaitu, jarum hisap (multi drawing needle), holder, tabung vakum, objek glass, mikroskop dan kamera.

\section{Metode}

Teknik pengambilan darah pada kuda dilakukan dengan cara vakum. Pengambilan sampel darah dilakukan melalui vena jugularis. Pembuluh darah dibendung dan daerah yang akan diambil darahnya dibersihkan menggunakan kapas yang telah dibasahi dengan alkohol $75 \%$. 
Selanjutnya dilakukan pengambilan darah menggunakanjarum hisap (multi drawing needle) dengan holder pada vena jugularis, kemudian tabung vakum dilekatkan pada jarum dan darah akan mengalir masuk kedalam tabung. Pembuatan preparat ulas darah dilakukan menggunakan duabuah objek glass, dimana ujung salah satu objek glass disentuhkan pada darah yang keluar kemudian ujung objek glass tersebut disentuhkan pada objek glass lainnya membentuk sudut $45^{\circ}$. Selanjutnya kedua objek glass digeser berlawanan arah secara cepat sehingga akan terbentuk ulas darah tipis pada objek glass. Setelah dikeringkan dengan cara mengangin-anginkan, sediaan ulas darah difiksasi menggunakan larutan methanol absolut selama limamenit, dan diwarnai dengan Giemsa 10\% selama \pm 50 menit kemudian dibilas menggunakan air mengalir dan dikeringkan. Preparat ulas darah yang telah diwarnai kemudian ditetesi dengan minyak emersi dan diamati dibawah mikroskop menggunakan pembesaran 1000X untuk mengidentifikasi keberadaan $T$. evansi. Jika ditemukan sampel yang positif dilanjutkan dengan penghitungan jumlah $T$. evansi per 10 (sepuluh) lapang pandang.
Data yang diperoleh pada penelitian ini disajikan secara deskriptif dan dianalisis dengan uji Chi-Square.

\section{HASIL DAN PEMBAHASAN}

\section{Hasil}

Dari hasil pemeriksaan pada 100 sampel darah kuda yang diambil di Desa Kabaru, Kecmatan Rindi, Kabupaten Sumba Timur ditemukan prevalensi sebesar 8\% (8/100) terinfeksi T. evansi.

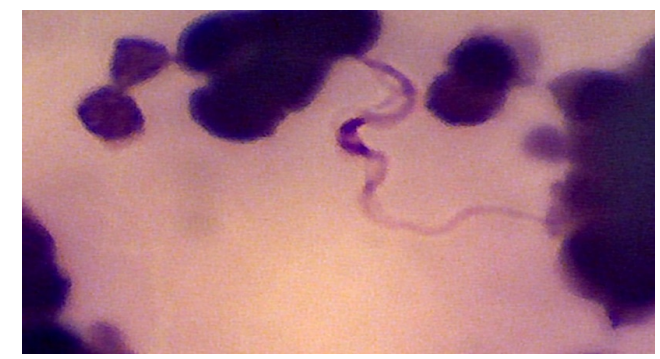

Gambar1. T. evansi pada Sampel Darah Kuda

Prevalensi infeksi T. evansi berdasarkan jenis kelamin, pada kuda jantan sebesar $12 \%(3 / 25)$ dan pada kuda betina sebesar $6.7 \% \quad(5 / 75)$. Setelah dianalisis dengan uji Chi-Square, menunjukkan tidak ada hubungan $(\mathrm{P}>0,05)$ antara jenis kelamin dengan prevalensi infeksi T. evansi (Tabel 1).

\section{Analisis Data}

Tabel 1. Prevalensi Infeksi T. evansi pada Kuda Berdasarkan Jenis Kelamin

\begin{tabular}{cccccc}
\hline Jenis Kelamin & Jumlah sampel & Positif & Negatif & Prevalensi (\%) & Sign. \\
\hline Jantan & 25 & 3 & 22 & 12 & \multirow{2}{*}{0.395} \\
Betina & 75 & 5 & 70 & 6.7 & \\
\hline
\end{tabular}

\section{Pembahasan}

Dari 8 sampel darah yang positif terinfeksi $T$. evansi ditemukan rata-rata intensitas infeksi 13 - 71 parasit T. evansi per 10 lapang pandang dengan rata-rata jumlah T. evansi sebesar $34.5 \pm 22.7$ (Tabel 2).

Berdasarkan hasil penelitian yang dilakukan di Desa Kabaru, Kabupaten Sumba Timur bahwa prevalensi infeksi $T$. evansi pada kuda sebesar $8 \%$. Prevalensi infeksi $T$. evansi sebesar $8 \%$ pada penelitian ini lebih besar jika dibandingkan dengan penelitian yang dilakukan oleh
Nadeem et al., (2010) pada kuda di Pakistan sebesar 2\% dan Radita (2017) pada kuda di Kabupaten Wajo, Sulawesi Selatan sebesar 4\% Hal ini berhubungan dengan pola pemeliharaan kuda di Desa Kabaru. Pada umumnya, kuda di Kabupaten Sumba Timur masih dipelihara secara tradisional yaitu dengan cara dilepas di padang gembalaan pada siang hari bersamaan dengan ternak lain seperti kerbau dan sapi kemudian malamnya dimasukkan kedalam kandang, ada pula yang dibiarkan di padang selama berbulanbulan (Dinas Peternakan Kabupaten 
Sumba Timur. 2015). Kuda yang diternakkan bersama dengan kerbau dan sapi menjadi salah satu faktor penyebab terjadinya infeksi $T$. evansi pada kuda, dimana kerbau dan sapi dapat bertindak sebagai reservoir infeksi $T$. evansi. DadiMamud et al. (2012) mengatakan bahwa tingginya infeksi parasit dapat disebabkan oleh manajeman lingkungan pemeliharaan yang buruk. Pengambilan sampel yang dilakukan pada musim kemarau juga mempengaruhi prevalensi pada penelitian ini. Padang penggembalaan biasanyamenghasilkan hijauan yang melimpah di musim hujan, dan musim kemarau mengalami kekeringan. Pada musim kemarau terjadi keterbatasan pakan bagi ternak, akibatnya ternak kurus dan kekurangan nutrisi. Kekurangan nutrisi merupakan salah satu faktor yang mempengaruhi infeksi $T$. evansi (Reid 2002).

Tabel 2. Intensitas Infeksi $T$. evansi pada Kuda di Desa Kabaru, Kecamatan Rindi, Kabupaten Sumba Timur

\begin{tabular}{cc}
\hline Sampel & $\begin{array}{c}\text { Jumlah } T \text {. evansi } / 10 \\
\text { lapang pandang }\end{array}$ \\
\hline 1 & 13 \\
2 & 32 \\
3 & 6 \\
4 & 58 \\
5 & 71 \\
6 & 17 \\
7 & 46 \\
8 & 33 \\
\hline
\end{tabular}

Rata-rata $\quad 34.5 \pm 22.7$

Prevalensi infeksi $T$. evansi sebesar $8 \%$ pada penelitian ini lebih rendah jika dibandingkan dengan penelitian yang dilakukan oleh Mastra (2011) secara serologis pada kuda di Pulau Sumbawa sebesar 13.43\%. Hal ini dikarenakan perbedaan kondisi geografis di daerah tersebut dan metode penelitian yang digunakan. Lokasi pengambilan sampel pada penelitian yang diakukan oleh Mastra (2011) banyak dijumpai sungai dan hutan dimana kondisi lingkungan seperti ini digemari oleh vektor lalat-latat pengisap darah. Prevalensi infeksi T. evansi pada penelitian ini juga lebih rendah dibandingkan dengan penelitian dilakukan oleh (Mueeid, 2010) pada kuda di Pakistan sebesar 16\%, Harrera et al. (2004) pada kuda di Pantanal Brazil sebesar 73\% dan Silva et al, (2016) pada kuda di Marajo Island, Brazi sebesar $8.23 \%$. Hal ini kemungkinan berhubungan dengan kondisi geografis di Desa Kabaru, Kecamatan Rindi, Kabupaten Sumba Timur yangterletak disepanjang pantai utara berbukit, memiliki curah hujan yang sangat rendah dan tidak merata, dimana musim kemarau relatif lebih panjang dibandingkan musim hujan. Dengan kondisi geografis yang demikian merupakan tempat yang kurang potensial bagi perkembangan vektor penyebar $T$. evansi (Tabanus, Stomoxys, Haematopota, Lyperosia). Hal ini dinyatakan oleh Desquesnes et al. (2013) bahwa status epidemiologik dan kondisi geografis dapat mempengaruhi kejadian penyakit Surra di suatu wilayah.Disamping itu waktu pengambilan sampel yang dilakukan pada musim kemarau juga kemungkinan mempengaruhi prevalensi pada penelitian ini. Selama musim hujan akan terjadi peningkatan jumlah vektor dibandingkan dengan musim kemarau. Menurut Herczeg et al. (2015) bahwa curah hujan, kelembapan udara dan sinar matahari berpengaruh terhadap banyaknya vektor khusunya Tabanus $s p$ di alam. Vektor membutuhkan suhu udara disekitarnya paling tidak $18^{\circ} \mathrm{C}$ untuk terbang. Suhu optimal bagi Tabanus sp untuk terbang minimal $31^{\circ} \mathrm{C}-35^{\circ} \mathrm{C}$. Suhu rata-rata di kabupaten Sumba Timur umumnya, $22,5^{\circ} \mathrm{C}-31,73^{\circ} \mathrm{C}$ (Badan Pusat Statistik Kabupaten Sumba Timur). Rendahnya prevalensi infeksi $T$. evansi pada penelitian inikemungkinan berhubangan dengan saat pengambilan sampel darah, dimana ternak di Desa Kabaru berada dalam masa pengobatan penyakit Surra (Dinas Peternakan Kabupaten Sumba Timur, 2016). 
Prevalensi infeksi T. evansi berdasarkan jenis kelamin, yaitu kuda jantan sebesar $12 \%$ dan kuda betina sebesar $6.7 \%$. Setelah dianalisis menggunakan Chi-Square, diperoleh tidak ada hubungan $(\mathrm{P}>0,05)$ antara jenis kelamin dengan prevalensi infeksi $T$. evansi. Penelitian pada unta yang dilakukan oleh Bhutto (2010) di Pakistan dan Kassa (2011) di Ethiopia juga menunjukkan hasil yang sama. Hal ini kemungkinankarena kuda jantan maupun kuda betina memiliki paparan yang hampir sama dengan vektor lalat di area penggembalaan. Perbedaan prevalensi pada kudajantan dan betina dipengaruhi oleh ketahanan dari inang itu sendiri. Reid (2002) menyatakan bahwa prevalensi penyakit Surra sering kali tidak berkaitan dengan klinis penyakit, harus ada faktor lain yang terlibat, seperti hewan kekurangan nutrisi, stress akibat dipekerjakan terlalu berat, patogenitas parasit dan strain parasit.

Intensitas infeksi $T$. evansi pada penelitian ini ditemukan $13-71$ parasit per 10 lapang pandang dengan rata-rata jumlah T. evansi sebesar $34.5 \pm 22.7$. Intensitas infeksi pada penelitian ini berhubungan dengan kondisi kuda yang digunakan sebagai sampel, dimana beberapa kuda hanya menunjukkan tanda klinis secara umum kelemahan, lesu, penurunan berat badan dan ada pula yang menunjukkan tanda klinis berupa edema pada abdomen. Hal ini sesuai dengan yang dikemukakan Desquesnes (2004) bahwa tanda klinis yang muncul dipengaruhi oleh intensitas infeksi T. evansi yang berkembang di sirkulasi darah. Intensitas infeksi $T$. evansi pada dasarnya tergantung pada kekebalan tubuh dan kondisi fisiologis dari hospes.

\section{SIMPULAN DAN SARAN}

\section{Simpulan}

Prevalensi infeksi $T$. evansi pada kuda di Desa Kabaru, Kabupaten Sumba Timur sebesar 8\%. pada kuda jantan sebesar $12 \%$ dan kuda betina sebesar
6.7\%. Sedangkan berdasarkan jenis kelamin pada kuda jantan sebesar $12 \%$ dan kuda betina sebesar $6.7 \%$. Tidak ada hubungan antara jenis kelamin dengan prevalensi infeksi $T$. evansi. Intensitas infeksi $T$. evansi pada sampel yang positif ditemukan 13-71 parasit per 10 lapang pandang dengan rata-rata jumlah $T$. evansi sebesar $34.5 \pm 22.7$.

\section{Saran}

Perlu dilakukan penelitian lebih lanjut untuk mengetahui pengaruh vektor dalam penularan infeksi $T$. evansi pada kuda sehingga dapat dilakukan suatu strategi pengendalian dan pencegahan infeksi T. evansi. Perubahan pola pemeliharaan kuda dengan memperhatikan manajemen kebersihan lingkungan yang baik juga perlu dilakukan untuk meminimalisir terjadinya infeksi $T$. evansi.

\section{UCAPAN TERIMA KASIH}

Penulis mengucapkan terima kasih kepada Dinas Peternakan Kabupaten Sumba Timur yang telah membantu dan memfasilitasi penulis dalam pengambilan sampel penelitian.

\section{DAFTAR PUSTAKA}

Bal MS, Amrita S, Ashuma, Balwinder KB, Kaur P and Singla LD. 2015. Detection and Management of Latent Infection of Trypanosoma evansi in a Cattle Herd. Indian J. Anim. Res. 48(1): 31-37.

Bhutto B, Gadahi JA,Shah G, Dewani P and Arijo AG. 2010. Field Investigation on the Prevalence of Trypanosomiasis in Camels in Relation to Sex, Age, Breed and Herd Size. Pak. Vet. J. 30(3): 175-177.

Coen PG, Luckins AG, Davison HC, and Woolhouse MEJ. 2001. Trypanosoma evansi in Indonesian buffaloes: evaluation of simple models of natural immunity to infection. Epidemiol. Infect. 126: 111-122.

Dadi-Mamud NJ, Kabir MA, Dibal DM, Rajab MH. 2012. Study on Prevalenceof Haemoparasites of 
Pigeon (Columbia livia) in LapaiNigeria. IJABR. 4(1\&2): 121-127.

Desquesnes M. 2004.Livestock Trypanosomoses and their Vectors in Latin America. Centre de coopération internationaleen recherche agronomique pour le développement (CIRAD)/Élevage et médecine vétérinaire tropicale (EMVT). ISBN: 92-9044-634-X.

Desquesnes M, Philippe H, De-Hua L, Alan D, Zhao-Rong L, and Sathaporn J. 2013. Trypanosoma evansi and Surra: A Review and Perspectives on Origin, History, Distribution, Taxonomy, Morphology, Hosts, and Pathogenic Effects. Bio. Med. Res. Int. 2013:22.

Eyob E, and Matios L. 2013. Review on camel trypanosomosis (surra) due to Trypanosoma evansi: Epidemiology and host response. J. Vet. Med. Anim. Health. 5(12): 334-343.

Herczeg T, Dénes S, Miklós B, András B, Mónika $G$, Róbert $F$ and Gábor $H$. 2015. The effect of weather variables on the flight activity of horseflies (Diptera: Tabanidae) in the continental climate of Hungary. Parasitol. Res. 114: 1087-1097.

Herrera HM, Da'vilab AMR, Noreka A, Abreuc UG, Souzab SS, D'Andread PS, Jansena AM. 2004. Enzootiology of Trypanosoma evansi in Pantanal, Brazil. Vet. Parasitol. 125: 263-275.

Tehsheen S, Jahan N, Desquesnes M, Shahzad MI, Qamar MF. 2016. Field investigation of Trypanosoma evansi and comparative analysis of diagnostic tests in horses from Bahawalpur, Pakistan. Turk. J. Vet. Anim. Sci. 41: 288-293.

Kassa T, Tadesse E and Hassen. 2011. Prevalence of camel Trypanosomosis and its vectors in Fentale district, South East Shoa Zone, Ethiopia. Vet. Arhc. 81: 611-621.
Laha R, and Sasmal NK. 2008. Endemic status of Trypanosoma evansi infection in a horse stable of eastern region of India - a field investigation. Trop. Anim. Health Prod. 40(5): 357-361.

Lehane MJ. 2005. The Biology of BloodSucking in Insects. Cambridge University Press.

Mastra IK. 2011. Seroprevalensi Trypanosomiasis di Pulau Sumbawa, Nusa Tenggara Barat. Bul. Vet. 23(79).

Metanawey-El, NadiaTM, El-Beih M, Abdel El-Aziz., Hassanane, MS and Abd El- Aziz TH. 2009. Comparative Studies on Diagnosis of Trypanosoma evansiin Experimentally Infected Goats. Global Vet. 3(4): 348-353.

Muieed MA, Chaudhary ZI, Shakoori AR. 2010. Comparative studies on the sensitivity of polymerase chain reaction (PCR) and microscopic examination for the detection of Trypanosoma evansi in horses. Turk. $J$. Vet. Anim. Sci. 34(6): 507-512.

Nadeem A, Asim A, Zafar IC, Kamran A, Khalid S, Nisar A, Ishtiaq A and Habib UR. 2010. Indirect fluorescent antibody technique based prevalence of Surra in equines. Pak. Vet. J. 31(2): 169-170.

Radita Besse Dewisari Nur. 2017. Deteksi Trypanosoma evansi pada Kuda (Equss caballus) di Kabupaten Wajo. Skripsi, Fakultas Kedokteran Hewan universitas Hasanuddin.

Reid SA. 2002. Trypanosoma evansi control and containment in Australasia. Trends. Parasitol. 18(5): 219-224.

Silva JAD, DomicianoI TO, MontãoI DP, Sousa PGS, Ramos LL, Paredes LJA, MonteiroI SG, Rivero GRC, Júnior ASPB, Duarte Cerqueira IABVD. 2016. Reemerging of natural infection by Trypanosoma evansi in horses in Arari, Marajó Island, Brazil. Ciência Rural, Santa Maria. ISSN 1678-4596. 